\title{
Dermatoglyphic patterns of female convicted criminals in Anambra state
}

\begin{abstract}
Dermatoglyphic is the study of epidermal ridges present on the hairless surfaces of the skin. This study was aimed to determine the dermatoglyphic patterns associated with criminal traits among female subjects in Anambra state. 100 female subjects constituting 50 female convicted criminals in Onitsha prison and 50 controls which comprises of female students and workers of Chukwuemeka Oduemegwu Ojukwu University, Uli campus. Details of crimes committed were obtained through an interviewed administered questionnaire on their consent to participate in the study. Hp Scanjet was used to scan their palm prints and saved as Jpeg image on a laptop. Dematoglyphic variables of fingerprint pattern of whorls, loops, arches, atd angles, total finger ridge counts (TFRC) and $\mathrm{a}-\mathrm{b}$ ridge counts were obtained using AUTOCAD 2015 installed in a laptop. Qualitative dermatoglyphic variables of whorls, loops and arches were found to differentiate criminals from the controls. Worthy of note was specified allocation of arch patterns on criminals' right thumb, right little finger and left thumb which were significantly different from the controls $(P<0.05)$. Total finger ridge counts of the criminals also showed significant differences compared with the controls. a-b ridge counts and atd angles showed no significant difference between the criminals and the controls $(\mathrm{p}>0.05)$. Fingerprint patterns of whorls, loops, arches can be used to differentiate criminals and non- criminals in our studied population, more precisely allocation of arch pattern on the right thumb, right little finger and left thumb among female subjects can be a sign of predisposition to criminality as shown in our study.
\end{abstract}

Keywords: dermatoglyphics, fingerprints patterns, criminal traits
Volume 6 Issue 4 - 2018

\author{
Ozor Nwafia Chinyere Pricilla,' Emelobe \\ Chidiebele Samuel, ${ }^{2}$ Igbigbi Patrick Sunday, ${ }^{2}$ \\ Ozor Chigozie Kenneth ${ }^{3}$ \\ 'Department of Anatomy, Chukwuemeka Odumegwu Ojukwu \\ University, Nigeria \\ ${ }^{2}$ Department of Anatomy, Delta State University, Nigeria \\ ${ }^{3}$ Department of Theatre Arts, Nnamdi Azikiwe University, \\ Nigeria
}

\begin{abstract}
Correspondence: Ozor Nwafia CP, Department of Anatomy, Faculty of Basic Medical Sciences, Chukwuemeka Odumegwu Ojukwu University, Uli, Nigeria, Email pricilliachinyere@gmail.
\end{abstract} com

Received: July 16, 2018 | Published: August 17, 2018

\section{Introduction}

The term dermatoglyphics was coined from two Greek words, Derms and Glyphics meaning skin and creases respectively. ${ }^{1}$ Fingerprints have been a critical tool for personal identification, most especially in detecting personal profile of a suspect in a crime scene, lifting of prints in a crime scene and comparing with the prints of a suspected persons have made dermatoglyphic studies crucial in forensic science. ${ }^{2}$ The dermatoglyphic patterns are developed during 12th to 13 th week of the intrauterine life and from this stage remain unchanged throughout the life. ${ }^{3}$ This accounts for its unique role in personal identification, specificity in convicting a criminal or a suspect in a crime scene and early detection of defects due to chromosomal abnormalities. ${ }^{4,5}$ The tendency to commit crime and dermatoglyphics have been reported to be genetically influenced, therefore it will be important to investigate the relationship between crime and dermatoglyphics. Prevalence of radial loops fingerprint patterns was reported by Ascraellli among prostitutes. ${ }^{1}$ White ${ }^{6}$ reported significant decrease in mean finger ridge count (TFRC) when compared to noncriminal population in Anglosaxon and Spanish population. ${ }^{7}$ The dermatoglyphic patterns of Ersher who killed 19 people (17 women), serving a sentence of life imprisonment was examined by Yarovenko ${ }^{8}$ and study showed whorl patterns in his both right and left digits.

Despite the studies enumerated above, no documented study as far as we know have been reported for female convicted criminals in Anambra state of Nigeria. This study tends to fill this gap in knowledge.

\section{Materials and methods}

100 female Nigerian subjects residing in Anambra state were examined using dermatoglyphic tools and interview-administered questionnaires to confirm their citizenship, as well as details of crimes committed as regards to our study group. This involved 50 volunteered female convicted criminals in Onitsha prisons, Anambra state, Nigeria and 50 volunteered female students and staffs of Chukwuemeka Odumegwu Ojukwu University, Uli campus, Anambra State who served as control matched for age and gender respectively. Both the convicts and control subjects gave informed consent to participate in the study. The subjects' palm prints were obtained by placing their palms on a Hp Scanjet with the thumb 300-400 along with the other digits $10-150$ abducted. This was necessary to produce clear palm prints. A preliminary study using 10 subjects in each group showed equal variance hence the use of $\mathrm{t}$-test for qualitative dermatoglyphic variables. The palm prints obtained, were recorded in a jpeg format in a laptop, then AutoCAD software version 2015 previously installed in the laptop was used to analyse the dermatoglyphic parameters of fingerprints patterns, atd angles and $\mathrm{a}-\mathrm{b}$ ridge counts according to improvised method of dermatoglyphic analysis by Oghenemavwe et al. ${ }^{9}$ Counting the pattern ridges of arches, whorls, loops according to the standard technique of Cummins \& Midlo ${ }^{10}$ The dermatoglyphic parameters analysed were subjected to statistical analysis using statistical package for Social Science Version 15 (SPSS) Chicago, Illinosis. Qualitative dermatoglyphic variables of fingerprint patterns (whorls, arches, loops) were evaluated with chi-square and quantitative dermatoglyphic variables (TFRC, atd angles, $\mathrm{a}-\mathrm{b}$ ridge counts) were evaluated by means and frequencies with $\mathrm{p}$-value less than $0.05(\mathrm{p}<0.05)$ was considered as significant.

\section{Results}

Higher frequencies of each patterns was observed on the right 
digits of the criminal group compared to the control group with a total percentages of $13.2 \%$ and $4 . * \%$ respectively (Table 1 ). Loops and whorls were significantly higher on the right digits of the control group than the criminal group with percentages of $31.0 \%, 25.6 \%$ and $14.2 \%$, $11.2 \%$ respectively (Table 1 ). Left digits of the criminals were also observed with significant increase in arch patterns with percentage of $8.4 \%$ compared to the control group with percentage of $3.0 \%$. Loop and whorl patterns were relatively higher in control group than the criminal group with percentages of $32.2 \%, 4.8 \%$ and $29.0 \%, 12.6 \%$ respectively (Table 2). The fingerprint pattern frequencies of the right and left digits of the control group were not significantly different ( $>0.05$ ), but in criminal group the fingerprint patterns of whorls, arches and loops on their left digits were statistically significantly different from that of their right digits $(\mathrm{p}<0.05)$ (Table 3 ). There was also no significant difference between the total finger ridge counts (TFRC), $a-b$ ridge counts and atd angles of the criminals and control groups respectively (Table 4) (Table 5) (Table 6)
Table I Right palms fingerprint patterns distribution in control and criminal groups

\begin{tabular}{llll}
\hline $\begin{array}{l}\text { Fingerprint } \\
\text { patterns }\end{array}$ & $\begin{array}{l}\text { Contro } \\
\text { (frequecies) }\end{array}$ & $\begin{array}{l}\text { Criminals } \\
\text { (frequencies) }\end{array}$ & Total percentages \\
\hline Whorls & $71(14.2 \%)$ & $56(11.2 \%)$ & $25.40 \%$ \\
Loops & $155(31.0) \%$ & $128(25.6 \%)$ & $56.60 \%$ \\
Arches & $24(4.8 \%)$ & $66(13.2 \%)$ & $18.00 \%$ \\
\hline
\end{tabular}

$P$ value, 0.001

Table 2 Left palms fingerprint patterns distribution in control and criminal groups

\begin{tabular}{llll}
\hline $\begin{array}{l}\text { Fingerprint } \\
\text { patterns }\end{array}$ & $\begin{array}{l}\text { Control } \\
\text { (frequencies) }\end{array}$ & $\begin{array}{l}\text { Criminals } \\
\text { (frequencies) }\end{array}$ & Total percentages \\
\hline Whorls & $74(14.8 \%)$ & $63(12.6 \%)$ & $27.40 \%$ \\
Loops & $161(32.2 \%)$ & $145(29.0 \%)$ & $61.20 \%$ \\
Arches & $15(3.0 \%)$ & $42(8.4 \%)$ & $11.40 \%$ \\
\hline
\end{tabular}

$P$ value, 0.001

Table 3 Left to Right palm fingerprint patterns cross-tabulation between the control and criminal groups

\begin{tabular}{|c|c|c|c|c|c|c|c|c|}
\hline \multicolumn{5}{|c|}{ Control group } & \multicolumn{4}{|c|}{ Criminal group } \\
\hline \multirow{2}{*}{$\begin{array}{l}\text { Fingerprint } \\
\text { patterns }\end{array}$} & \multirow{2}{*}{$\begin{array}{l}\text { Left palm } \\
74\end{array}$} & \multirow{2}{*}{$\begin{array}{l}\text { Right } \\
\text { palm }\end{array}$} & \multicolumn{2}{|c|}{ Percentages } & \multirow{2}{*}{$\begin{array}{l}\begin{array}{l}\text { Left } \\
\text { palm }\end{array} \\
63\end{array}$} & \multirow{2}{*}{$\begin{array}{l}\text { Right palm } \\
56\end{array}$} & \multicolumn{2}{|c|}{ Percentages } \\
\hline & & & $29.00 \%$ & $P$ value $=0.324$ & & & $23.80 \%$ & $P$ value $=0.033$ \\
\hline Loops & 161 & 155 & $63.20 \%$ & & 145 & 128 & $54.60 \%$ & \\
\hline Arches & 15 & 24 & $78.00 \%$ & & 42 & 66 & $21.60 \%$ & \\
\hline
\end{tabular}

Table 4 Independent sample t-test of total finger ridge counts (TFRC) between control and criminal groups for both right and left palms

\begin{tabular}{llll}
\hline Control & & Criminals & \\
\hline Fingers(status) & Mean \pm SD & Mean \pm SD & P values \\
\hline RFI & $10.88 \pm 5.97$ & $6.74 \pm 6.90$ & 0.02 \\
RF2 & $10.84 \pm 5.14$ & $9.16 \pm 6.40$ & 0.151 \\
RF3 & $12.64 \pm 5.71$ & $9.94 \pm 6.61$ & 0.031 \\
RF4 & $15.14 \pm 5.01$ & $12.74 \pm 6.57$ & 0.043 \\
RF5 & $12.68 \pm 4.10$ & $10.68 \pm 5.70$ & 0.047 \\
LFI & $13.80 \pm 7.21$ & $8.82 \pm 7.52$ & 0.001 \\
LF2 & $12.16 \pm 5.35$ & $9.40 \pm 6.35$ & 0.021 \\
LF3 & $12.04 \pm 4.53$ & $10.72 \pm 5.08$ & 0.173 \\
LF4 & $14.60 \pm 4.53$ & $13.58 \pm 5.03$ & 0.29 \\
LF5 & $11.78 \pm 3.92$ & $10.64 \pm 5.29$ & 0.224 \\
Total & $127.16 \pm 37.36$ & $102.24 \pm 50.50$ & 0.006 \\
\hline
\end{tabular}

Table 5 Independent Sample t-test of a-b ridge counts between control group and criminals for both right and left palms

\begin{tabular}{llll}
\hline Control & \multicolumn{3}{c}{ Criminals } \\
\hline Status & Mean \pm SD & Mean \pm SD & P value \\
\hline a-b Left Palm & $39.36 \pm 5.36$ & $39.78 \pm 3.90$ & 0.655 \\
a-b Right Palm & $37.76 \pm 5.17$ & $38.12 \pm 4.93$ & 0.722 \\
\hline
\end{tabular}


Table 6 Independent Sample t-test of atd angle between control and criminal groups for both right and left palms

\begin{tabular}{llll}
\hline Control & \multicolumn{3}{c}{ Criminals } \\
\hline Status & Mean \pm SD & Mean \pm SD & P-Value \\
\hline Left Palm & $43.60 \pm 4.79$ & $43.78 \pm 4.63$ & 0.849 \\
Right Palm & $42.80 \pm 5.06$ & $42.56 \pm 5.16$ & 0.849 \\
\hline
\end{tabular}

\section{Discussion}

Our study have shown significant higher frequencies of arch patterns on both right and left digits of the female convicted criminals compared with controls. This was in concordance with Biswas ${ }^{11}$ who worked on Indian Juvenile criminals.

Prevalence of arch patterns was observed on the right first digits (right thumb), right fifth digits (little finger) and left first digit which was different from the control group.

Campbel1 ${ }^{12}$ in a German population reported previously studied reported that individuals with greater frequencies of aches were characterized as repressive, secretive in self defense, naturally suspicious and resentful of others achievement. In our study individuals convicted for child trafficking, murder and robbery were found with arch patterns on their right first digit (right thumb), right fifth digits (right little finger), and left first digit (left thumb). Studies have previously shown that qualitative dermatoglyphic variables differ between races and ethnic groups and also between the right and left palms and digits. ${ }^{13,14}$

There was significant higher occurrence of arch patterns on both left and right digits of the criminals compared with the control group, however, loops and whorl patterns showed no significant difference between the criminal and control groups.

Whorl and loop patterns were relatively higher on the left and right digit of the control compared with the criminals, and this was in line with the study conducted by Agarwal ${ }^{15}$.

Furthermore, getting define individual with greater frequencies of arches as crude, insensitive, hardhearted and definitely stubborn. In the same vein, Katakhar classified these individuals as high strong, nervous and too easily responsive to emotional stimulation. ${ }^{12}$ In the current study, right first digit (RFI) of the control was observed with a higher mean value of $10.88 \pm 5.97$ compared to the criminals with mean value of $6.74 \pm 6.90$ and the difference was statistically significant $(\mathrm{P}<0.05)$. The total finger ridge counts (TFRC) of the right third digit $\left(R F_{3}\right)$, right forth digits $\left(R_{4}\right)$, right fifth digits $\left(R_{5}\right)$, left first digit $\left(\mathrm{LF}_{1}\right)$, and left second digits $\left(\mathrm{LF}_{2}\right)$ of the criminals were found to be statistically significantly different from the controls $(\mathrm{P}<0.05)$. Our study showed no significant difference between criminals and controls in quantitative variables except TFRC as indeed was the case with a study of male convicted criminals reported previously in a Nigerian population. ${ }^{16}$ This study also demonstrated dermatoglyphic difference in qualitative variables as this study has shown.

In conclusion, this study has clearly shown differences in dermatoglyphic traits between female convicted criminals and controls in qualitative dermatoglyphic variables of arches, whorls and loops. Similarly TFRC can also differentiate convicted female criminals from controls but this was not the case with convicted male criminals in a Nigeria study previously documented. ${ }^{16}$ For female convicted criminals in our studied population, both qualitative variables and only one quantitative variable of TFRC can differentiate them from female controls and hence can serve as possible markers from the identification of potential female criminals in our studied population.

\section{Authors contribution}

Ozor-Nwafia C.P participated fully in the conception and analysis of the data. Emelobe C.S was involved in analysis and interpretation of data. Prof. P.S Igbigbi participated in interpretation of data, while Ozor C.K was in involved in social communication with the subjects, also in describing various traits among the subjects.

\section{Acknowledgements}

None.

\section{Conflict of interest}

Author declares that there is no conflict of interest.

\section{References}

1. Cummius H, Midlo C. Fingerprints, palms and soles. An introduction to Dermatoglyphics. New York, USA: Dover Publications; 1961:333.

2. Cummins H. Morphology of the palmar hypothenar dermatoglyphics in man. Hum Biol. 1935;7:1-23.

3. Kiran K, Kavitha Rai, Amitha M Hedge. Dermatoglyphics a noninvasive diagnostic tool in predicting mental retardation. J Int Oral Health. 2010;2(1):95-100.

4. Jones KL, Smith DW, Vlleland CN, et al. Patterns of malformation in offspring of chronic alcoholic mother. Lancet. 1973;1(7815):12671271.

5. Kobyhiansky E. Relationship between genetic anomalities of different levels and deviations in dermatoglyphics traits. Part 2: Dematoglyphic Peculiarities of Females with Turner's Syndrome. Anthropol Anz. 1997;55(3-4):315-348.

6. White NG. The use of digital dermatoglyphics in assessing population relationships in Aboriginal Australia. Birth Defects Orig Artic Ser. 1979; 15(6):437-454.

7. Quintana Castilla A. Dermatoglyphics study in a Spanish penal population. In: Waldimir Wertelecki, Chris C Plato, editors. Dermatoglyphics fifty years later. New York: Alan R Liss Inc; 1979:800.

8. Yaroivenko V. Study of the relationship of papillary pattern criminal conduct of human. Asian Soc Sci. 2015;11(16):349-354.

9. Oghenemavwe EL, Osaat RS. An improvise easy digital method for palmar dermatoglyphics. Biosci \& Bioeng. 2015;1(3):85-59.

10. Cummins H, Midlo C. Palmar and plantar epidermal ridge configurations in European Americans. An J Plays Anthropol. 1926;9(4):471-502.

11. Biswas PC. Finger and palmar print of the Indian juvenile criminals. The East Anthropologist. 1945;3:124-127.

12. Campbell ED. Fingerprints and palmar dermatoglyphics. 1998.

13. Igbigbi PS, Didia BS, Owhojedo H. Comparative palmar and digital dermatoglyphics of Hausa and Urhobo ethnic groups in Nigeria. West Afr J Anat. 1996;4:51-58.

14. Igbigbi PS, Msamati BC. Palmar and digital dermatoglyphic patterns in Malawian subjects. East Afr Med J. 1999;76(12):668-671

15. Agarwal KK, Dutt HK, Saxena A. General assumption of psychological behaviour. Based on fingerprint patter. J Biol Life Sci. 2012;3(1):59-65.

16. Igbigbi PS, Ominde BS, Emelobe SC. Dermatoglyphic traits of male convicted criminals compared with controls in a Nigerain population. West Indian J Med. 2018. 